as an honorary member of the Academy of Sciences of the U.S.S.R., it was recalled by M. Maisky that in 1831, Michael Faraday was also elected an honorary member of the Academy. Such events emphasise the internationalism of science. In Russia, since the revolution, new scientific institutes, laboratories and universities have been built, and science has made great progress; metallurgy in particular has been encouraged. In this work, Russia readily accepts foreign assistance. In his reply, Sir Robert Hadfield said that, to him, Russia is the land of Mendeléeff, whose work has been of fundamental importance in chemistry. He also spoke of the work of the well-known Russian metallurgist, the late Demetri Tschernoff, who did pioneer work on the metallography and scientific heat treatment of steel at a time when only empirical methods were used. His work, introduced to Great Britain by the late Sir William Anderson, led to the formation in 1881 by the Institution of Mechanical Engineers, of a special committee, of which Tschernoff was himself a member, to report on the heat treatment of steel ; this committee is still in existence as the Alloys Research Committee. Referring to the Iron and Steel Institute, Sir Robert pointed out that there are, at present, fourteen Russian members, and he expressed the hope that this number will be increased, with the future developments of science in that country. Sir Robert Hadfield's name is, of course, associated with manganese and silicon steels, and when speaking of Russia's vast mineral resources, he naturally singled out manganese, which is much used in the production of high quality steel as well in the special alloy steels. Enormous deposits of this manganese ore occur in the valley of the Kvirila River, and Sir Robert anticipates heavy production during the next twenty years. Sir Robert concluded with a tribute to the interest in scientific development which is being shown in Russia.

\section{Locomotion in Sponges}

A NEW and valuable light was thrown on the vexed question of locomotion in sponges by Mr. M. Burton at a meeting of the Zoological Society on February 21. Mr. Burton had been asked to investigate some sponges growing on the filter-beds of the Society's Aquarium, as it was feared these might interfere with the circulation of the water. He found that even the adults were capable of moving appreciable distances to secure a more favourable area for feeding. Movement in post-larval, and young sponges, he pointed out, had been recorded on several occasions ; but it was now apparent, for the first time, that even fully-grown individuals could change their position. This discovery has an important bearing on our conceptions of the biology of sponges. So far from being 'typically sedentary animals', as they are described in textbooks - the victims of chance and circumstance-it is now established that they can, or at least in some species, exercise some selection as to habitat, the movement being a directive locomotion, carried out by amœboid extensions of the ectosome.
THIs new discovery by Mr. Burton follows hard upon his observations on unattached sponges, published in the "Discovery" reports 1932, wherein it is shown that some species, and individuals of many other species, habitually lead a free existence, and are capable of being transported by currents. In this respect his observations on the sponges in the filter-beds in the Aquarium of the Zoological Gardens are particularly interesting. The individuals of this species, as yet unnamed, are very easily detached by small Crustacea, and are sufficiently buoyant to move several inches, in still water, as the result merely of a shrimp swimming by. Thus, at all ages, either by their own movement, or by being transported by currents, sponges are far from being the irrevocably fixed animals they have hitherto been supposed to $b e$.

\section{Australian Dairy Cattle Research Council}

THE dairying industry in Australia is becoming alarmed at the prevalence of contagious abortion and contagious mastitis (mammitis) in milking herds. At the instance of the pure-bred cattle breeders of New South Wales, an Australian Dairy Cattle Research Council has been set up with headquarters in Sydney and a liaison committee in each State. It will work in close association with the Commonwealth Council for Scientific and Industrial Research and the State Departments of Agriculture, but will seek its funds from other than government sources and will be free from political control. The Australian Dairy Council, a body concerned mainly with marketing problems, has promised $£ 2,000$ a year for five years towards the cost of investigations, and other contributions are confidently expected. The work on abortion will be centred at the Glenfield Veterinary Research Station in New South Wales, while the mastitis work will be carried on in Victoria, probably with the University of Melbourne as headquarters.

\section{Ritual at $\mathrm{Ur}$}

Mr. C. L. Woolley's first report on the excavations of the current season at Ur (Times, March 3), dealing mainly with a building of the little-known First Dynasty, about 3000 B.c., below the platform of Ur-Engur's ziggurat, records several features which are new, some of them by no means readily susceptible of explanation. It would appear that a ziggurat, now sheathed in the later tower, occupied the middle of a platform, in the north and east corners of which were temples of the moon god. In describing the eastern temple, Mr. Woolley directs attention to the extraordinary thickness-some fifteen feet-of the brick floor of the approach chambers which led to the open ziggurat terrace. For this, the only explanation he has to offer is that it had some religious purpose. Again, in the courtyard are two circular structures of brick, which would be regarded as bases for columns, if it were not for their great diameter of thirteen feet. The suggestion that they were intended as the bases for altars is supported by the existence nearby of a brick-built basin sunk in the floor. In an adjacent room is a circular hearth for the great cauldron in which the food of the god was prepared. 